\title{
PENYELESAIAN SENGKETA BISNIS DI LUAR PENGADILAN ANTAR WARGA SUKU SASAK DI PULAU LOMBOK $^{1}$
}

\author{
Idrus Abdullah ${ }^{2}$
}

\begin{abstract}
Abstrak
This study took place within the entire autonomous region on the island of Lombok, which is in West Lombok regency/city of Mataram, Lombok Central, and East Lombok District. Perhatan focus of this research is to find answers to "how the people on the island of Lombok, Sasak tribe resolve their business disputes, the procedures undertaken, and the legal rules that are used", a series of problems to study. From the result, obtained by the findings that show the models out of court settlement of disputes between fellow citizens Sasak, including debt-related accounts, buying and selling cars, buying and selling of precious metals, with reference to the local values (the customs, habits, tradisis-traditional, religious values) are used as terms of reference the parties dispute to end the disputes. Results showed process fast, simple, easy and cheap that is based on principles of fairness, deliberation, the agreements that were led by religious leaders, community leaders as mediators. In this circuit, the parties dispute tends to avoid the courts to resolve disputes with reason "could damage the relationship of brotherhood" (social relations), in addition to the perception that only "those who were disputing only" who took the court mechanism. Within the above framework, this study refers to the theory of "Legal Pluralism" from Griffiths, the theory of "Semi-Autonomous Social Fields" from Sally Folk Moore, in addition to the theory of the "Living Law" from Erlich. All data obtained were processed according to the rules prevailing methodological qualitative research, and then analyzed to obtain a deep understanding of the important aspects implicit in a series of studies the object of dispute. Evaluation and data analysis take place simultaneously, with the final result
\end{abstract}

1 Penelitian dengan mengambil judul "Penyelesaian Sengketa Bisnis Di Luar Pengadilan Antar Sesama Warga Sasak di Pulau Lombok" ini, merupakan kelanjutan dari kerjasama untuk riset unggulan (RUKK) dengan Kementerian Ristek RI (melalui Lembaga Penelitian Universitas) untuk anggaran Tahun 2005, yang diawali dengan penelitian di pulau Sumbawa berkenaan dengan "Penyelesaian Sengketa Bisnis Di Luar Pengadilan Antar Sesama Warga Sumbawa, dan antar sesama Warga Bima/Dompu (2004).

${ }^{2}$ Penulis adalah Dosen Fakultas Hukum Universitas Mataram. Alamat korespondensi Magister Ilmu Hukum Unram, Jalan Majapahit No. 62, Lombok, mataram. 
of the conclusions, the arguments that give the full picture of the whole process of studies showing the interrelation between the various research findings with the concept of fact-theoretic grip author.

Kata kunci: resolusi sengketa, mediasi, pranata lokal

\section{Pendahuluan}

Penelitian dengan mengambil judul "Penyelesaian Sengketa Bisnis Di Luar Pengadilan Antar Warga Suku Sasak di Pulau Lombok", merupakan kelanjutan dari penelitian dengan fokus yang sama pada warga masyarakat di pulau Sumbawa. Pentingnya penelitian ini terutama dilihat dari kecendrungan kegiatan bisnis masyarakat yang semakin tinggi dengan ratusan ragam transaksi sehari-hari, berarti semakin tinggi kemungkinan terjadinya sengketa yang menuntut penyelesaiannya. Sejalan dengan pemahaman ini, maka diperlukan suatu model atau mekanisme penyelesaian sengketa bisnis yang dapat diterima, baik sistem, maupun kemampuannya yang tidak tergantung kepada mekanisme peradilan umum. Model penyelesaian sengketa demikian ini, dalam praktik dikenal dengan Alternative. Dispute Resolution (ADR) (negosiasi, mediasi, arbitrase, konsiliasi), atau melalui mekanisme "pranata lokal" (adat atau hukum adat, kebiasaan-kebiasaan, tradisi-tradisi) yang dibangun oleh kelompokkelompok sosial di lingkungannya masing-masing".

Berbagai model penyelesaian sengketa yang tidak tergantung kepada proses berperkara di pengadilan, lebih merupakan praktik-praktik kebiasaan dalam bentuk pranata-pranata tradisional yang diakui hukum dan adat lokal dalam banyak budaya masyarakat. Dalam rangkaian ini, dapat diikuti beberapa contoh penyelesaian kasus-kasus hukum dengan menggunakan cara-cara lokal, baik berkaitan dengan bisnis, maupun di bidang lainnya, seperti: "Penyelesaian Sengketa Melalui Mekanisme Pranata Lokal, Studi Kasus Dalam Dimensi Pluralisme Hukum Pada Area Suku Sasak di Lombok Barat. $^{3}$ Dalam penelitian ini, diungkapkan bagaimana warga suku Sasak di Kabupaten Lombok Barat menyelesaikan sengketa mereka dalam bidang sengketa tanah, warisan, atau dalam hal perkawinan di Lombok Barat; Atau penelitian berkaitan dengan sengketa berdimensi bisnis, yakni antar sesama

${ }^{3}$ Idrus Abdullah, Penyelesaian Sengketa Melalui Mekanisme Pranata Lokal: Studi Kasus Dalam Dimensi Pluralisme Hukum Di Lombok Barat, Disertasi. Jakarta: U1, 2002. 
suku Sumbawa atau sesama suku Bima/Dompu, ${ }^{4}$ atau "Penyelesaaan Sengketa Bisnis Di Luar pengadilan antar "étnis lokal" (etnis Sasak, Sumbawa, dan Bima/Dompu) vs "etnis pendatang" (etnis Tionghoa) di Nusa Tenggara Barat. Dalam penelitian ini antara lain terungkap bahwa etnis Tionghoa untuk menyelesaikan sengketa besnisnya lebih memilih negosiasi daripada ke pengadilan. Orang-orang Tionghoa selalu mengacu kepada falsafah Confusius dalam setiap sengketa yang timbul, karena lebih mengutamakan harmoni daripada konflik. Demikian juga dengan penyelesaian sengketa melalui mekanisme adat pada masyarakat Data Taman (Kalimantan Barat) yang dikenal dengan "Lembaga Musyawarah Kombong", Dengan adanya lembaga adat ini, demikian Anyang, jarang sekali sengketa di dibawa ke luar dari lingkungan adat Jika terdapat perkara-perkara yang ditangani oleh petugas negara dan menjatuhkan hukuman sesuai kehendak peraturan tertulis, diurus lagi berdasarkan adat lingkungan bersangkutan. Pada masyarakat Batak Karo, juga dikenal dengan "Runggun Adat", dimana "anggota yang hadir ikut terlibat dan mengambil bagian dalam setiap penyelesaian sengketa" dengan dibimbing oleh anggota yang dipercaya memiliki kemampuan selaku penasehat, "... all the participants are involved as members of one of these categorios, not because they are god friends ...".

Penyelesaian sengketa di luar [pengadilan banyak digunakan, karena dipandang efesien, cukup memuaskan pihak-pihak bersengketa, dan banyak memebrikan kemudahan-kemudahan yang tidak diproleh dalam proses pengadilan resmi. Para pihak terpuaskan karena konflik tidak menjadi terbuka dan melebar, lebih menekankan harmoni dan kekeluargaan, sehingga sengketa-sengketa hukum yang menurut peraturan resmi dapat diajukan ke pengadilan, "telah selesai" di luar pengadilan, Meminjam Galanter, "...sebagian besar diselesaikan melalui perundingan-perundingan antara pihak bersengketa, atau melalui forum yang merupakan bagian (bersumber dari pada) lingkungan sosial dimana sengketa itu timbul ...". Pada bagian lain Galanter mengemukakan, bahwa "penyelesaian sengketa tidak hanya ditemukan di tempat pengadilan resmi atau forum-forum yang disponsori oleh negara, melainkan juga dalam institusi-institusi sosial primer, seperti keluarga, lingkungan tempat tinggal, kerja, hubungan kekerabatan, hubungan-hubungan bisnis, dan lain sebagainya, sebagai pranata-pranata sosial dari sistem norma dan aturan-aturan lokal sesuai tradisi yang dipertahankan oleh masyarakat di lingkungannya..

Di kota-kota besar di Indonesia, diperkirakan model penyelesaian sengketa bisnis dengan lebih mengutamakan kesepakatan-kesepakatan atau

${ }^{4}$ Penyelesaian Sengketa Bisnis Di Luar Pengaddilaan Antar Warga Sesama Etnis di Pulau Sumbawa, 2004. 
prosedur di luar pengadilan sudah mulai dipraktikkan, baik di kalangan usahawan besar, maupun pengusaha menengah atau pengusaha kecil, bahkan di pusat-pusat perdagangan di perkotaan, di pasar-pasar, atau di pusat-pusat transaksi lainnya, diselesaikan melalui kesepakatan-kesepakatan, atau dengan mengacu kepada tradisi-tradisi, atau kebiasaan-kebiasaan lokal yang sering diperaktikkan oleh mereka-mereka yang bersengketa.

Dalam rangkaian ini, menjadi layak dipertanyakan bagaimanakah orang-orang Sasak yang bergerak di dunia bisnis pada pusat-pusat transaksi di pulau Lombok mengakhiri sengketa hukum bisnis mereka, dan apakah ada perbedaan dalam hal mekanisme yang ditempuh oleh pihak-pihak bersengketa bisnis di pulau Sumbawa? ? $^{5}$ Apakah dalam setiap sengketa, mereka lebih memilih mekanisme alternatif penyelesaian sengketa, daripada mengajukan sengketanya ke pengadilan resmi? Pertanyaan-pertanyaan ini belum terjawab, karenanya perlu diteliti. Pertanyaan-pertanyaan demikian itu menjadi penting, mengingat bahwa kebutuhan hukum masyarakat tidak hanya terpenuhi melalui lembaga-lembaga hukum formal saja, karena pemenuhannya juga tersalur melalui praktik-praktik kebiasaan orang-orang dalam mengakhiri sengketa-sengketa bisnis di lingkungannya masingmasing.

Dalam kerangka berbagai pemikiran di atas, penelitian ini dilakukan untuk menganalisis berbagai bentuk "penyelesaian sengketa di luar pengadilan" (Alternative Dispute Resolution - ADR), dengan penekanan pada sengketa-sengketa hukum yang terjadi dalam dunia bisnis antar sesama etnis sasaran penelitian (antar warga sasak dengan warga Sasak), baik bersifat individual, maupun kelompok.Melalui analisis kasus-kasus sengketa dimaksud, diharapkan dapat terungkap prosedur-prosedur dan prinsip-prinsip penyelesaian sengketa hukum yang dianut oleh mereka yang bersengketa, jenis-jenis sengketa, "awal mula terjadinya sengketa, nilai-nilai budaya penting yang berpengaruh dalam masyarakat tempat timbulnya sengketa, cara-cara penyelesaian sengketa, di samping akibat-akibat hukum dan sosial yang ditimbulkannya". Dalam tahapan ini, pada gilirannya akan diperoleh jawaban-jawaban yang mengungkapkan bagaimana pelaku bisnis di pulau Lombok menyelesaikan sengketa dalam berbagai bidang usaha mereka.

${ }^{5}$ Idrus Abdullah, Op. Cit., 2004. 


\section{Tinjauan Pustaka}

Dalam buku "Sejarah Daerah Nusa Tenggara Barat", 6 diungkapkan bahwa pulau Lombok dengan masyarakatnya yang dikenal dengan sebutan suku "Sasak", seluruhnya adalah penganut Islam yang. taat, dan ketaatan mereka dimanifestasikan ke dalam berbagai bentuk ibadah, baik kepada Tuhannya (hamblum min Allah), maupun dalam hubungannya dengan sesama sebagai manusia (hamblum min annaas), sesuai dengan hukumhukum yang bersumber dari firman-firman Ilahia (Al-Qur'an), atau berdasarkan Hadist yang mencerminkan ucapan, perbuatan, nilai-nilai, dan praktik-praktik Rasul Muhammad.

Ketaatan atas ajaran-ajaran Islam, tidak lepas dengan pengaruh pemuka-pemuka masyarakat dan Tuan-Tuan Guru dalam penyebaran Islam yang dilakukan secara sistematis dan didukung oleh pengikutnya yang setia, telah menghantar kelompok relegius ini pada posisi strategis selaku pimpinan informal yang dihormati dalam struktur sosial masyarakat Sasak pada umumnya, baik di bidang politik (pemerintah), sosial-kemasyarakatan. Mengikuti pesan dan perintah Tuan Guru adalah simbol ketaatan seseorang kepada pemimpinnya, sami' naa wa atha' naa - kami mendengar dan kami taat, mencerminkan kepatuhan total masyarakat atas ajaran-ajaran Islam dalam bayang-bayang kharismatika Tuan-Tuan Guru ulama Islam berpegaruh meluas di kalangan komunitas Sasak.

Ajaran-ajaran Islam dalam paham ini, tetap memberikan toleransi kepada adat lokal untuk dipertahankan sebagai bagian dari sistem pranata masyarakat, sepanjang tidak bertentangan dengan norma-norma Islam, dan dikemudian hari dikenal dengan sistem pranata yang disebut "adatgama" (hukum "adat" dan hukum "agama"), yakni dialektika antara norma-norma universal dan norma-norma lokal. Bersandar kepada doktrin lokal ini, berarti masyarakat tidak dapat sepenuhnya melepaskan diri dari pranata-pranata adat mereka, bahkan tua-tua adat setempat memiliki posisi sama pentingnya untuk keteraturan kehidupan sosial di samping pemuka-pemuka Islam sebagai acuan primer. Karena, pranata-pranata lokal, seperti: hukum adat, adat-istiadat, kebiasaan-kebiasaan, tradisi-tradisi, selalu dalam kontrol hukum agama, bahwa "adat bersandarkan agama", atau dalam bahas lokal orang-orang Sasak diucapkan dengan istilah "adat luir gama". Jika terdapat pertentangan diantara keduanya, maka adat harus dirubah dengan cara mengakomodasikannya ke dalam nilai-nilai Islam". Keadaan ini berarti bahwa dalam pengertian demikian itu, masyarakat dalam kehidupannya

${ }^{6}$ Departemen Pendidikan dan Kebudayaan RI, "Sejarah Daerah Nusa Tenggara Barat", (Departemen Pendidikan dan Kebudayaan RI, 1977-1978), hal. 45-46. 
sehari-hari dihadapkan dengan serangkaian norma sebagaii aturan-aturan hidup yang dapat dijadikan kerangka acuan dalam bertindak.

Dikemukakan oleh Sally Folk Moore, dalam tulisannya "LingkunganLingkungan Sosial yang Semi-Otonom", bahwa "warga masyarakat pada umumnya merupakan anggota dari lingkungan-lingkungan sosial yang masing-masing memiliki aturan-aturan internalnya sendiri-sendiri. Pengaruh aturan-aturan eksternal (baca: hukum negara - pen.), banyak tergantung kepada sifat-sifat internal dari lingkungan sosial tersebut". Dalam rangkaian ini Moore mengatakan, lingkungan sosial (sosial field) memiliki kemampuan untuk menimbulkan dalam lingkungannya sendiri berbagai aturan normatif, dan dalam lingkungan-lingkungan sosial yang semi otonom itu masingmasing individu saling berinteraksi, bernegosiasi, dan dalam proses itu muncul aturan-aturan yang mereka ciptakan sendiri (self-regulation) yakni sebagai "hukum yang dibangun berdasrkan kesepakatan-kesepakatan diantara mereka yang bersengketa" untuk mengakhiri sengketa-sengketa yang timbul.

Konsep "Lingkungan-Lingkungan Sosial yang Semi Otonom" dari Moore di atas, agaknya sejalan dengan pandangan deskriptif tentang "pluralisme hukum" (legal pluralism) dari Griffiths. ${ }^{8}$ Ia mengatakan, "sưatu keadaan dimana dalam bidang-bidang sosial perilaku tunduk kepada lebih dari satu tatanan hukum" (the legal pluralism as that state of affairs, for any social field, in which behaviour pursuant to more than one legal order accurs). Berdasarkan pandangan ini, berarti pihak-pihak bersengketa "mempunyai akses kepada sejumlah sejumlah sistem hukum" (choice of law), sebagai dasar tindakannya termasuk dalam pengertian untuk menyelesaiakan sengketa-sengketa bisnis" Keadaan ini, juga tercermin dalam Griffiths yang secara tegas memberikan uraiannya yakni: "perlu ditekankan adanya berbagai pengaturan normatif lainnya". Dia mengatakan, "tidak semua hukum merupakan state law, dan juga tidak benar bahwa semua hukum diatur dan ditetapkan (administrated) oleh perangkat negara (baca: ditetapkan oleh pengadilan - pen.) yang tunggal"

Dari butir-butir pandangan di atas, memberikan penjelasan bahwa terdapat keaneka-ragaman hukum yang berlaku dalam masyarakat yang dapat dijadikan kerangka acuan bertindak, yakni di samping hukum undangundang (state law), juga beroperasinya ketentuan tingkah-laku yang hidup

${ }^{7}$ Sally Folk Moore, "Law and Social Change: The Semi-Autonomous Social Field an as Appropriate Subjeck of Study, Law as Process- an Anthropological Approach", (London. Boston: Routledge Kegan Paul 1983), hal. 59.

${ }^{8}$ Griffiths, What is Legal Pluralism? Journal of Legal Pluralism, 24. (London: Miller \& Tunner Ltd., 1986), hal. 1-50. 
dalam masyarakat, atau dari perspektif Erlich disebut dengan "hukum yang hidup" (Living Law). ${ }^{9}$ Erlich dalam tulisannya Theory off The Lioving Law mengemukakan, "hukum yang hidup" adalah "sebagai hukum yang mendominasi kehidupan itu sendiri, yakni berupa kumpulan harapan-harapan normatif, tingkah-laku dari individu-individu". Selanjutnya ia mengatakan "aturan-aturan mengenai tingka-laku adalah fakta sosial yang merupakan hasil dari kekuatan-kekuatan yang beroperasi dalam masyarakat, dan dalam bertingkah-laku mereka nyata-nyata berpedoman kepada aturan-aturan tersebut, yakni aturan-aturan hukum, aturan-aturan moral, aturan-aturan agama, norma-norma sosial, etika, kehormatan, norma-norma kepantasa, aturan-aturan tentang apa yang bijak, dan yang tidak. Aturan-aturan itu tidak dapat dipisahkan dengan masyarakat dimana norma-norma itu bekerja" ("Rules of conduct, are a social facts, the resultants of the forces that are operative in society, and can no more be considered separate and apart from society, in which are operative ...")

\section{Metoda Penelitian}

Penelitian ini mengambil lokasi pada 3 (tiga) Kabupaten dan 1 (satu) Pemerintahan Kota, yakni Kabupaten Lombok Barat, Kabupaten Lombok Tengah, Kabupaten Lombok Timur, dan Kota Mataram, sebagai daerah otonom yang berada di Pulau Lombok. Studi ini bertitik tolak pada ilmu hukum, dengan fokus kajian hukum sebagai hal empirik dan terekspresi dalam tingkah laku. Suatu analisis hubungan antara hal-hal yang normatif dengan aktivitas-aktivitas sosial konkrit dengan pendekatan "kasus-kasus sengketa" (trouble case mathod), bercorak kualitatif (qualitative research). Penelitian kualitatif - seperti diungkapkan oleh Bencha Yoddumnem-Attig, ${ }^{10}$ "adalah dengan menunjuk karakteristis dari data kualtitatif yakni "bersifat alamiah (sesuai kodrat), variatif, memiliki kedalaman dan dalamnya informasi. Data kualitatif, dapat memggambarkan "arti" dan "proses" tingkah laku yang menjadi pusat penelitian dari ilmu-ilmu sosial". Sejalan dengan pandangan ini, adalah seperti dikatakan oleh Moleong, " bahwa "keunggulan

\section{${ }^{9}$ Ibid.}

${ }^{10}$ Bencha Yoddumnem-Attig, Bencha Yoddumnem-Attig, et.al. (ed), "Field Manual on Selected Qualitative Research Methods", (Thailand Institiute for Population and Social Research, Mehido University, 1991), hal. 11.

11 Lexi J. Meleong, "Metodologi Penelitian Kualitatif", (Bandung: PT. Remaja Rosdakaria, 1999), hal. 8. 
penggunaan metoda kualitatif karena ia menyajikan secara langsung hakikat hubungan antara peneliti dan responden, maupun informan (pihak-pihak bersengketa dan mereka yang terlibat dalam penyelesaian sengketa - pen.), dan metoda ini lebih peka dan lebih dapat menyesuaikan diri dengan banyak pengaruh, dan pola nilai-nilai yang berlaku"

Seluruh data yang diperoleh, diolah menurut hukum-hukum metodologis yang lazim berlaku pada penelitian kualitatif. Data yang ditemukan (berupa kasus-kasus), diidentifikasikan berdasarkan sifat dan jenis kasus, kemudian dianalisis untuk memperoleh pemahaman mendalam atas aspek-aspek signifikan yang tersirat dalam serangkaian kasus obyek studi, kemudian menghasilkan kesimpulan-kesimpulan dengan menggunakan metoda induktif. Penggunaan analisis induktif, berarti merupakan suatu proses berpikir dari "bawah" ke "atas", yakni dari fakta-fakta konkrit (berupa kenyataan-kenyataan realita bersifat umum, dikumpulkan dari yang paling berhubungan), kemudian ditarik kesimpulan-kesimpulan ke arah yang bersifat khusus. Misalnya, "bahwa masyarakat suku Sasak di pulau Lombok pada umumnya menggunakan tradisi-tradisi, kebiasaan-kebiasaan, dalam menyelesaikan setiap masalah sosial kemasyarakatan yang timbul" (proses berpikir umum). Dengan demikian, "warga masyarakat Sasak selalu mengacu kepada tradisi-tradisi atau kebiasaan-kebiasaan mereka dalam menyelesaikan sengketa bisnisnya" (proses berpikir khusus). Dalam rangkaian ini, tulisan ini akan mengambil 5 (lima) kasus sengketa bisnis dari keseluruhan hasil Riset Unggulan (RUKK) pada tahun 2005 yang berjumlah 7 (tujuh) kasus. Pengambilam 5 (lima) sengketa bisnsi dalam tulisan ini, tidak akan memepengaruhi substansi hasil penelitian, karena secara metodologis penelitian yang bersifat "studi kasus" yang diutamakan bukan "jumlah kasusnya", tapi lebih kepada "kasusnya" sendiri. Hasil akhir dari data yang dikumpulkan di lapangan, merupakan temuan-temuan bersifat empiris, kesimpulan-kesimpulan, argumentasi-argumentasi yang memberikan gambaran secara utuh dari seluruh proses kajian yang menunjukkan interelasi antara berbagai fakta dengan dengan konsep-konsep teoritik berkenaan dengan obyek studi.

\section{Hasil Penelitian dan Pembahsaan}

Berdasarkan kegiatan penelitian yang dilakukan pada komunitas suku Sasak di Pulau Lombok yang berlangsung kurang lebih 6 (enam) bulan pada Tahun 2005, diperoleh sejumlah data atau fakta empiris berupa berbagai penyelesaian sengketa bisnis di luar pengadilan yang dilakukan antar warga dari etnis bersangkutan sebagaimana dikemukakan berikut ini. 
Sengketa Bisnis 1: Sengketa Hutang-Piutang Barang Dagangan (Tahun 2001), antara $\mathrm{H}, \mathrm{Mhn} / 45$ thn, selaku "penggugat" (selanjutnya disingkat P) lawan Amq Skri/40 tahun selaku "tergugat", selanjutnya disingkat T). Daerah penelitian Kecamatan Tanjung Kabupaten Lombok Barat.

Sengketa bisnis ini terjadi berawal dari adanya kelalaian pihak $\mathrm{T}$ selaku pembeli barang-barang kelontong di toko P. Setelah jatuh tempo pelunasan, ternyata $T$ tidak dapat memenuhi kewajibannya. Selengkapnya, dikemukakan oleh $\mathrm{P}$ selaku penjual, ${ }^{12}$ kurang lebih sebagai berikut: "T mengambil barang dagangan di toko saya berupa barang-barang kelontong untuk dijual kembali dengan harga seluruhnya Rp. 9 (sembilan) juta. "Pada saat transaksi, T tidak membayar seluruh harga barang, masih tersisa Rp. 4 (empat) juta, dan akan dibayar 1 (satu) bukan kemudian, Setelah jatuh tempo pembayaran, $\mathrm{T}$ ingkar janji, walaupun beberapa kali dilakukan penagihan, baik langsung, maupun melalui jasa baik keluarga dekat $\mathrm{T}$, tetap saja tidak melunasi hutangnya. Mengingat $\mathrm{P}$ dan $\mathrm{T}$ bertempat tinggal pada desa yang sama, akhirnya P meminta bantuan $\mathrm{H}$. Mnf/59 thn (kepala Desa yang juga merangkap sebagai kepala adat setempat) sebagai "mediator" untuk menyadarkan T atas kewajibannya". Dari penuturan H. Mnf/49 thn, membenarkan bahwa ia pernah menyelesaikan sengketa hutang-piutang antara $\mathrm{P}$ dan $\mathrm{T}$ selaku warga masyarakatnya.

Menurut pengakuan T, keterlibatan $\mathrm{H}$. Mnf dalam sengketa ini, telah mendorong $\mathrm{T}$ untuk memenuhi kewajibannya dengan alasan "ia merasa tidak tenang" dan "tidak enak" dengan warga masyarakat di lingkungannya, terutama dengan keterlibatan keliang (kepala adat - pen.) mendorong ia untuk menyelesaikan hutangnya. Dari penuturan "mediator", bahwa hukum yang digunakan untuk mengakhiri sengketa adalah "kebiasaan-kebiasaan yang mencirikan budaya masyarakat dengan menjunjung tinggi nilai-nilai persaudaraan antara sesama warga". Karenanya, lanjut mediator, dengan karakterisitik nilai-nilai budaya demikian ini, warga masyarakat jarang sekali menempuh mekanisme pengadilan, karena di samping gedung pengadilan yang letaknya di Mataram berada jauh dari desa kami, juga masyarakat tidak terbiasa berperkare (baca bersengketa - pen.) di pengadilan", karena dapat merusak hubungan sosial.

Pada bagian lain dikemukakan oleh $\mathrm{H}$. Mnf. Selaku "mediator" dengan bahasa lokalnya yang kental, "ite selseang masalah perkare warge tedasarang menurut kemele sa' besia bareng bake keluarga nine-mame" (kami mengakhiri sengketa mereka atas dasar kesepakatan yahg diumbuhkan oleh pihak-pihak bersengketa dengan melibatkan keluarga masing-masing -

${ }^{12}$ Wawancara yang dilakukan Penulis pada tanggal, 12 Juni 2005. 
pen.). Setelah kedua belah dipertemukan, kemudian mereka membangun kesepakatan-kesepakatan, dan akhirnya $\mathrm{T}$ bersedia untuk segera melunasi hutangnya. Tahapan selanjutnya, demikian mediator, sesuai tradisi mereka diminta untuk saling "berjabatan-tangan" kemudian disusul oleh keluarga masing-masing pihak bersengketa, sebagai simbol bahwa sengketa mereka telah diakhiri dengan kekeluargaan, menghilangkan permusuhan diantara mereka.

Sengketa Bisnis 2: Sengketa Jual-Beli Gabah antara H. Zndin Ar/55 Thn (P) lawan "L. Wrks/50 Thn (T). Daerah penelitian di desa Prina, Kecamatan Jonggat, Kabupaten Lombnok Tengah (Thn 2000). P dan T adalah mitra dalam usaha jual-bali gabah dan beras, dimana $\mathrm{P}$ menjual gabah kepada $\mathrm{T}$ dan oleh $\mathrm{T}$ gabah dijadikan beras untuk dijual kembali. Kemitaraan usaha diantara mereka sudah lama dirintis sehingga tumbuh saling percayamempercayai.

Seperti diceritakan oleh $\mathrm{P},{ }^{13}$ bahwa awal mula terjadinya sengketa adalah pada 1999 seperti biasanya T membeli gabah kepada P sebanyak 4 (empat) ton dengan harga seluruhnya Rp. 8 juta. Sesuai kesepakatan, harga gabah baru akan dibayar oleh $\mathrm{T}$ dalam tenggang waktu 3 (dua) minggu terhitung sejak transaksi. Sesuai tradisi, dalam transaksi jual-beli gabah ini tidak mengikuti persyaratan-persyaratan sebagaimana dikehendaki hukum formal, namun dibangun berdasarkan kesepakatan-kesepakatan, dilakukan secara lisan yang dilandasi saling percaya. Dalam transaksi $T$ ingkar janji, dan untuk memelihara hubungan baik, $\mathrm{P}$ memberikan kelonggaran 1 minggu lagi kepada $\mathrm{T}$ untuk memenuhi kewajibannya, namun tetap saja $\mathrm{T}$ lalai. Akhirnya, P meminta bantuan tokoh agama (H. Jydi/50 tahun) setempat sebagai "penengah" untuk mengakhiri sengketa mereka. Informasi ini dibenarkan oleh L. Wrks selaku tergugat, ${ }^{14}$ sambil mengatakan dengan bahasa lokalnya "tiang nde man ara kepeng, tiang nde semel pade Ka' Tuan Jydi, pasti tiang baye selapu hutang tie, lema, (kurang lebih artinya "saya belum ada uang untuk membayar, saya merasa segan dengan kehadiran H. Jydi, Insya Allah dalam waktu dekat hutang saya akan saya lunasi semuanya pen.).

Dari pengakuan $\mathrm{T}$ di atas, terungkap bahwa $\mathrm{T}$ tergerak untuk membayar hutangnya di samping adanya rasa "bersalah" (baca kesadaran sosial - pen.), juga karena pengaruh keterlibatan "pemuka agama/ masyarakat" yang bertindak selaku "penengah" mengakhiri sengketa bisnis mereka. Pendirian "rasa bersalah, seperti dikatakan oleh mediator,

${ }^{13}$ Wawancara yang dilakukan Penulis pada Juli 2005.

${ }^{14}$ Wawancara yang dilakukan Penulis pada Juli 2005. 
"merupakan bagian dari ajaran agama dan adat yang menuntun warga untuk berperilaku baik. Ditanyakan tentang "hukum" yang digunakan unjtuk mengakhiri sengketa ini, ia mengatakan: "warga masyarakat di sini tidak begitu paham tentang aturan-aturan hukum resmi, (state law - pen.), mereka lebih memahami ajaran-ajaran agama, kebiasan-kebiäsan, tradisi-tradisi, yang mengatur kehidupan sosial-budaya dan ekonomi masyarakat seharihari". Dalam menyelesaikan semua masalah, selalu mengacu kepada musyawarah untuk mencapai kesepakatan. "Orang-orang di wilayah ini, lanjut H. Jydi dengan penuh semangat, "warga masyarakat jika sedang mengalami masalah, lebih mengutamakan peran orang-orang yang "dituakan" untuk penyelesaiannya, karena dirasakan adil dan memahami cara-cara berpikir warga masyarakatnya. Masyarakat pada umumnya mengetahui jika mereka bersengketa di pengadilan dapat berakibat hubungan sosial menjadi rusak, pihak-pihak bersengketa dan keluarga cendrung bermusuhan, bahkan tidak ngomong selama-lamanya". Informasi mediator ini juga dibenarkan oleh kepala Desa setempat, L. Drsh/48 Tahun, Masyarakat pada umumnya, lanjut kepala Desa, "mengetahui jika mereka bersengketa di pengadilan dapat berakibat hubungan sosial menjadi rusak, pihak-pihak bersengketa dan keluarga cendrung bermusuhan, bahkan tidak ngomong selama-lamanya".

Sengketa Bisnis 3: Jual Beli Kendaraan Roda Empat (Tahun 1999)/ HM.Akldn/47 thn (P) lawan Amaq Prm/49 thn (T). Lokasi penelitian, Kelurahan Ampenan Utara, Kecamatan Ampenan, Kota Mataram (tempat tinggal P), dan Desa Mantang, Kecamatan Mantang, Kabupaten Lombok Tengah (tempat tinggal $\mathrm{T}$ ).

Sengketa berawal dari sikap $\mathrm{T}$ yang tidak memenuhi prestasi tepat waktu sesuai yang diperjanjikan. Selengkapnya sebagaimana diceritakan oleh P (wawancara, 2 Agustus 2005) kurang lebih sebagai berikut: "pada bulan Maret tahun 1999, P membeli tunai mobil bekas kepada T mitra bisnisnya, dan di saat transaksi jual-beli T sebagai penjual menyerahkan mobilnya tanpa dilengkapi BPKB dan berjanji (secara lisan) bahwa BPKB akan diserahkan 1 (satu) bulan kemudian dengan alasan karena BPKB masih dijadikan agunan oleh T di salah satu Bank Pasar (BPR). Pada saat jatuh tempo T tidak memenuhi janjinya, dan oleh $\mathrm{P}$ ia diberi kelonggaran 1 (satu) bulan lagi untuk menyerahkan BPKB. Pada akhir April, T tetap saja tidak dapat memenuhi kewajibannya. Sejak itu, P mendiamkan saja kasusnya tanpa melakukan tindak-tindakan tertentu sesuai hukum yang berlaku". Sementara itu, $T$ selaku penjual tidak membantah semua informasi yang diberikan oleh $\mathrm{P}$, bahkan $\mathrm{T}$ sendiri menyadari atas kesalahannya berkenaan dengan tidak dapat memenuhi kewajiban hukumnya, dengan alasan saat-saat itu belum memiliki uang untuk menebus BPKB yang dijadikan jaminan di Bank. 
Menjawab pertanyaan peneliti, "mengenai sistem hukum yang digunakan dalam menyelesaikan sengketanya, $\mathrm{P}$ menjawab "dengan caracara yang dianggap baik oleh masyarakat, orang-orang memiliki rasa malu, tata-krama, kebiasaan-kebiasaan yang selama ini berlaku". P yang tamat Madrasah Aliyah (sederajad SLTA) ini melanjutkan keterangannya dengan bahasa lokal setempat, "bile nyekenne arak masalah" (jika sedang ada masalah - pen) masyarakat cendrung menghindari penyelesaian-penyelesaian bersifat resmi. Saya pah+am, bahwa ada juga "hukum pemerintah" (state law - pen.) untuk menyelesaikan setiap masalah", tapi masyarakat tidak begitu mengenalnya. Bersengketa (di pengadilan - pen), menurut paham P "sama artinya merusak hubungan persaudaraan, kami berusaha menyelesaikan setiap masalah berkaitan dengan bisnis dengan tidak saling menyakiti. Dari keterangan $\mathrm{P}$, memperlihatkan bahwa mekanisme pengadilan merupakan mekanisme yang tidak akrab dengan budaya masyarakat setempat Masyarakat memiliki cara-cara tersendiri untuk mengakhir sengketa sesuai dengan kebiasaan dan tata-kerama, mekanisme pengadilan dinilai dapat merusak kemitraan dalam berbisnis.

Sengketa ini berakhir setelah keterlibatan H. Smd (60 tahun) selaku pihak ketiga yang diminta oleh pihak-pihak bersengketa sebagai "penengah". $\mathrm{H}$. Smd, juga merupakan keluarga dekat $\mathrm{T}$ yqng memiliki pengaruh sosial meluas di wilayahnya. Setelah H. Smd bersilaturrahmi ke rumah T bersama dengan $\mathrm{P}$ dan sama-sama duduk bersila di rumah tengah rumah $\mathrm{T}$ yang juga dihadiri oleh keluarga $T$ untuk sama-sama mengikuti fatwa $H$. Smd. Dalam proses ini, demikian $\mathrm{P}$, dengan disaksikan oleh keluarganya $0 \mathrm{~T}$ memberikan kesanggupan untuk menyerahakan BPKB dalam waktu 2 minggu kemudian. Kesediaan $\mathrm{T}$ memenuhi kewajibannya, di samping untuk memelihara hubungan baik dengan P, juga "saya malu" dengan keluarga saya (H. Smd. pen.) yang datang bersama $\mathrm{P}$, dan jika saya tidak memenuhi kewajiban, saya akan dicemoohkan oleh keluarga sendiri", demikian $T$ memberikan pengakuannya.

Dalam rangkaian di atas, memperlihatkan suatu penyelesaian sengketa dengan mekanisme sederhana dan cepat. Dalam kasus ini pihak P cukup "didampingi" seseorang membawa pesan-pesan bersifat kekeluargaan kepada $\mathrm{T}$, dan pada akhirnya diperoleh penyelesaian dimana $\mathrm{T}$ akan segera memenuhi prestasinya. Dari informasi ini juga diketahui adanya "pengaruh keluarga atau kerabat dekat" sedemkian kuatnya, sehingga $T$ tergerak hatinya untuk membayar hutang, "jika tidak saya penuhi saya akan dicemoohkan oleh keluarga sendiri".

Melengkapi informasi di atas, dikemukakan oleh kepala Desa setempat, sambil menggunakan bahasa lokalnya, ia mengatakan: "semeton selapu endik kemele berperkare ara pengadilan, mangke bau besia same- 
same semeton" ("masyarakat semuanya tidak mau bersengketa di pengadilan, karena berakibat bermusuhan dengan sesama saudara" - pen.). Dari informasi terakhir ini, menjelaskan bahwa masyarakat lebih mengutamakan pentingnya "nilai-nilai komunal" daripada kepentingan warga sebagai individu-individu, dimana aspek kebersamaan merupakan acuan utama mereka dalam mengatasi setiap persoalan sosial-kemasyarakatan yang timbul dalam kehidupan mereka sehari-hari.

Sengketa Bisnis 4: Hutang-Piutang Dalam Jual-Beli Ikan basah dan ikan Asin (Tahun 2001), antara Hj. Sohr/54 tahun (P), lawan H. Sukr/43 tahun (T). Daerah penelitian Desa Labuhan Lombok, Kecamatan Pringgasbaya, Kabupaten Lombok Timur.

Terjadinya sengketa antara dua orang yang sama-sama bergerak di bidang jual-bali ikan ini, berawal dari $\mathrm{T}$ yang tidak memenuhi prestasi sesuai batas waktu yang telah disepakati Selengkapnya diceritakan oleh P (wawancara, 3 Agustus 2004), kurang lebih sebagai berikut: "selama T menjalin kemitraan bisnis dengan $\mathrm{P}$, ia selalu memenuhi kewajibannya berdasarkan kesepakatan (lisan) yakni bahwa setiap T mengambili ikan pada $\mathrm{P}$ untuk pembayarannya baru dilakukan setelah ikan yang diambil $\mathrm{T}$ terjual habis. Namun, lanjut $P$, pada transaksi terakhir $T$ mengambil ikan dalam jumlah yang cukup besar dengan nilai kurang-lebih Rp. 6 juta (ikan basah dan ikan tri/kering). Sejak pengambilan terakhir, $T$ tidak melakukan pembayaran sebagaimana biasanya dan keadaan ini berlangsung sampai dengan 1 (satu) bulan, namun tetap tidak ada tanda-tanda $T$ memenuhi prestasinya walaupun sudah dilakukan beberapakali penagihan, demikian $\mathrm{P}$ mengakhiri penuturannya". Semua keterangan P dibenarkan oleh $T$, dan bahkan ia mengaku kalau belum dipenuhinya prestasi kepada $\mathrm{P}$ hanya karena dana dari hasil penjuaklan ikannya belum terkumpul semua.

Adapun prosedur yang ditempuh untuk menegakhiri sengketa, adalah dimana pihak-pihak betsengketa bernegosiasi langsung untuk mencapai kesepakatan. yakni petemuan kehendak antara para pihak yang didasarkan oleh nilai-nilai kekeluargaan. Dari hasil kesepakatan, akhirnya, $\mathrm{T}$ bersedia melunasi semua hutangnya dalam tenggang waktu 15 hari sejak kesepakatan dilahirkan. Pada waktu pembayaran, ikut menyaksikan beberapa rekan bisnis lainnya sebagai usaha "membersihkan" nama baik $\mathrm{T}$ di hadapan sesama pedagang ikan, demikian P mengakhiri ceritanya. Mengutip H. Dg. Krm (53 tahun) berkenaan dengan penyelesaian sengketa. Ia menyatakan "musyawarah atau damai merupakan pelaksanaan hukum yang utama, sehingga dapat menghindari pertikain berkepanjangan diantara pihak-pihak bertikai". Dari pernyataan ini, menjelaskan bahwa masyarakat pedagang di daerah ini dalam setiap, menyelesaikan sengketa, lebih mengutamakan caracara lokal sejalan dengan kebiasaan yang berlaku diantara mereka, daripada 
mengacu kepada sistim hukum tertulis (state law - pen.) yang tidak banyak dipahami oleh masyarakat, khususnya oleh para pedagang.

Dalam peristiwa hukum ini, terlihat suatu penyelesaian sengketa bisnis lebih mengutamakan prosedur daripada substansi. Hukum, dalam arti "hukum negara" (badan peradilan) sebagaimana juga diakui oleh oleh T, "tidak akan menyelesaikan masalah secara tuntas, karena masih ada yang "tersisa" yakni berupa ketidak-puasan para pihak karena harus menempatkan mereka pada posisi "kalah" dan "menang", jelas bertentangan dengan prinsip-prinsip kekeluargaan yang dianut selama ini oleh para pedagang ikan di wilayah Lombok Timur dan sekitarnya". Dalam rangkaian ini, lanjut $T$, "belum ada seorang pedagangpun dari kelompok kami yang menyelesaikan sengketanya melalui pengadilan", demikian T mengakhiri penuturannya.

Menjawab pertanyaan penulis tentang kemungkinan menggugat ke pengadilan, dikemukakan oleh P kurang lebihn sebagai berikut: "bersengketa di pengadilan sama artinya "membuka kesalahan sendiri" di mata masyarakat, khususnya kepada sesama mitra bisnis. Masyarakat tidak akan menilai siapa yang "salah" dan siapa yang "benar", namun yang diketahui bahwa ke pengadilan merupakan penyimpangan tradisi. Penyelesaian di pengadilan, lanjut $\mathrm{P}$, berarti kami "bersengketa", padahal kami tidak dalam posisi demikian. Jika kami ke pengadilan berarti kami dalam keadaan "bermusuhan" dan jelas bertentangan dengan pesan-pesan dari adat kebiasaan kami yang didasarkan pada ajaran agama dengan mengisyaratkan "pade-pade semeton, endik bagus bersia" - sesama saudara tidak dibenarkan bermusuhan". Demikian P dengan bahasa lokalnya, dan dengan nada yang sama juga diakui oleh T selaku lawan sengketa P".

Dari berbagai data penelitian di atas, diperoleh beberapa pengetahuan yang menjelaskan terdapat beberapa faktor yang mendorong pihak-pihak bersengketa mengindari pengadilan. Hal yang paling berpengaruh adalah hilangnya kepercayaan dari mitra bisnis terhadap mereka yang mengajukan sengketanya ke pengadilan, karena dinilai "ada perbuatan tidak jujur" yang dilakukan oleh salah satu pihak yang bersengketa.

Sengketa Bisnis 5 : Jual-Beli Perhiasan Mas Tahun 2002), antara M. $\mathrm{Tfq} / 35$ tahun (P) lawan Tanwi/45 tahun (T). Daerah penelitian, Desa Pringgabaya, Kecamatan Pringabaya, Kabupaten Lombok Timur, dan lingkungan Sukarbela, Kec. Ampenan, Kota Mataram.

$\mathrm{P}$ dan $\mathrm{T}$ sudah lama bermitra dalam bidang usaha mas perhiasan, namun dalam suatu kesempatan $\mathrm{T}$ dianggap lalai memenuhi prestasinya kepada P. Selengkapnya diceritakan oleh $\mathrm{P}^{15}$ sebagai berikut: " $\mathrm{T}$ adalah "pandai emas" yang cukup dikenal, kemudian saya menyerahkan emas

${ }^{15}$ Wawancara yang dilakukan Penulis pada tanggal, 10 Agustus 2004. 
dengan berat 500 gram Kepada $\mathrm{T}$ untuk dijadikan perhiasan dengan desain yang berbeda-beda. Namun, pada saat $\mathrm{T}$ menyerahkan seluruh hasil pekerjaannya, lalu saya timbang kembali ternyata emas yang sudah berbentuk perhiasan tersebut mengalami penyusutan seberat kuang lebih 45 gram. Sedangkan menurut standar normal, penyusutan untuk emas seberat 500 gram paling banyak $5-7,5 \%$ saja. Atas dasar itu saya menanyakan kepada $T$, tapi ia berusaha mengelak dengan alasan emas batangan yang saya serahkan beratnya bukan 500 gram, tapi hanya 450 gram dan akan mengalami penyusutan $10 \%$ setelah menjadi perhiasan, demikian alasan $\mathrm{T}$ kepada saya". Pada bagian lain dikemukakan oleh P, "kami masih berselisih paham "namun saya tetap menerima seluruh mas yang sudah dijadikan perhiasan oleh $\mathrm{T}$ dengan maksud supaya dapat segera dipasarkan kembali.

Dalam kasus ini memperlihatkan penomena berbisnis yang tidak lazim, dimana antara $\mathrm{P}$ dan $\mathrm{T}$ masih dalam keadaan berselisih namun $\mathrm{P}$ bersedia menerima penyerahan barang obyek perselisihan, tanpa harus terlebih dahulu menyelesaikan persoalan pokoknya yakni "mengenai perbedaan perhitungan berat emas diantara mereka". Menjawab pertanyaan peneliti, "mengapa $\mathrm{P}$ bersedia menerima barang yang masih dalam masalah"? P mengatakan "saya tidak menghendaki persoalan kami berkembang menjadi sengketa - dan saya bersedia menerima barang yang masih bermasalah dengan maksud agar diantara saya dengan $\mathrm{T}$ tidak terjadi sengketa yang berkepanjangan, dan itu artinya kami akan bermusuhan". Term "sengketa", seperti diungkapkan oleh $\mathrm{H}$. Hsb/48 tahun warga setempat yang cukup terpelajar, (wawancara, 23 Juni 2004) "sama dengan berbicara "hak" dan "kewajiban" dan penyelesaiannya hanya di pengadilan. Senada dengan pemahamn ini, dalam kesempatan lain diungkapkan oleh P,"jika terjadi masalah antara sesama mitra bisnis tidak diartikan dalam keadaan "bersengketa", karena bersengketa hanya ada di pengadilan, demikian P mengakhiri keterangannya.

Diketahui, bahwa penyelesaian sengketa ini dilakukan di depan TGH (Tuan Guru Haji) Mrd/62 tahun, seorang tokoh agama kharismatik. Dalam penyelesaian ini, $\mathrm{T}$ bersedia memberikan ganti rugi kepada $\mathrm{P}$ dalam bentuk uang kontan untuk harga 45 gram mas atau setara dengan harga setengah 7,5 $\%$ dari penyusutan seperti yang diklaim oleh $\mathrm{T}$. Dengan kesediaan $\mathrm{T}$, berarti ia mengakui kesalahannya, dan setelah itu hubungan mereka menjadi baik kembali seperti tidak pernah ada masalah diantara mereka, demikian $\mathrm{H}$. Murd. mencoba meyakinkan peneliti.

Melalui mekanisme penyelesaian yang ditempuh oleh pihak-pihak bersengketa, memperlihatkan prinsip-prinsip musyawarah yang dilandasi oleh nlia-nilai kebersamaan. Dalam proses demikian, tercermin bahwa penyelesaian sengketa lebih mementingkan nilai kekeluargaan yang 
didasarkan prinsip-prnsip keadilan antar sesama mitra bisnis, menghindari permusuhan, dengan mengutamakan kelangsungan kemitraan, daripada sekedar mempertahankan prinsip-prinsip bisnis universal yang dikenal individualistik dan formalis, dan cendrung memposisikan mitra bisnis sebagai "lawan" atau "musuh" bila timbul sengketa diantara mereka. Prinsip-prinsip berbisnis demikian ini, agaknya tidak populair dalam praktik budaya suku bangsa Sasak, mengingat bahwa dalam berbisnis yang dikejar bukan semata-mata keuntungan sebagai hal yang utama, namun keteraturan nilai-nilai komunal yang mencerminkan budaya bisnis orang-orang Sasak.

Dari serangkaian data penelitian berupa sengketa-sengketa bisnis di luar pengadilan yang diperoleh sebagaimana terungkap di atas, secara faktual memperlihatkan bahwa oeang-orang Sasak di pulau Lombok dalam menyelesaikan sengketa bisnisnya pada umumnya menghindari pengadilan formal dengan alasan "pengadilan tidak sesuai dengan budaya hukum mereka. Pihak-pihak bersengketa lebih memilih mekanisme atau prosedur "mediasi', suatu prosedur yang mudah, singkat dan biaya ringan, bahkan "tanpa biaya", dengan menghadirkan "pihak ketiga" selaku "mediator". Pihak mediator yang dipercayakan oleh pihak-pihak bersengketa adalah orang-orang yang secara sosial memiliki otoritas atau pengaruh. Pengaruh dimaksud, terbentuk baik karena presepsi-presepsi, ide-ide, masyarakat terhadap orang-orang atau figur-figur tertentu, maupun karena pengaruh sistem nilai (adat-istiadat atau norma-norma Islam). Orang-orang atau sekelompok orang yang memiliki otoritas tersebut, adalah pemuka-pemuka agama, pemuka masyarakat, atau tua-tua adat, dan secara fungsional, mereka adalah pemimpin-pemimpin tradisional (pimimpin informal) dalam berbagai aspek kehidupan sosial-kemasyarakatan yang mampu mengarahkan atau merubah perilaku warga masyarakat di lingkungannya "untuk berbuat" atau "tidak berbuat". Praktik penyelesasian sengketa suku Sasak dalam penelitian ini, secara sosial menunjukkan adanya perbedaan mekanisme yang ditempuh dengan warga masyarakat di pulau Sumbawa, dimana pada umumnya lebih mengutamakan mekanisme "negosiasi" daripada "mediasi". Keadaan ini, antara lain didasarkan pertimbangan adanya "budaya malu" yang dianut oleh sebagian warga masyarakat di kedua komunitas (Sumbawa, Bima/Dompu). Secaea budaya, pihak-pihak bersengketa cendrung tidak menghendaki keterlibatan "pihak ketiga" (baca diketahui oleh masyarakat) untuk mengakhiri sengketa hukum mereka (Idrus Abdullah, 2004)

Dalam konteks sistem norma "adat" dan "nilai-nilai agama" yang dijadikan kerangka acuan bertindak oleh suku bangsa ini, menunjukkan peranan "nilai-nilai budaya" dan "ajaran agama" sebagai suatu kebutuhan dalam rangka terbentuknya "hukum yang hidup", suatu kompromi sosial dan orientasi hukum masyarakat. Jika diletakkan dalam perspektif dialektika 
masyarakat dan budaya hukum (legal culture and society), bermakna menjelaskan secara empiris peran dari sistem tata-nilai yang mendorong terbentuknya suatu bangunan normatif itu, dan sampai pada sintesis hukum yang menempatkan eksistensi nilai-nilai kultural dan ajaran agama sama pentingnya dalam kerangka kehidupan bersama. Dengan demikian, fungsi sosial dari ajaran agama untuk keteraturan tatanan masyarakat di wilayah ini, dari cara pandang antropologis terdapat interelasi positif antar "nilai-nilai agama" dengan "nilai-nilai budaya" berupa adat-istiadat, kebiasaankebiasaan, tradisi-tradisi, dimana keduanya merupakan idiologi perekat dalam realitas masyarakat pada suku bangsa Sasak, dan secara historis suku bangsa ini memang dikenal sebagai penganut agama yang taat. Proses pembentukan pranata hukum tersebut, menunjukkan bagaimana sistem normatif itu muncul dan berkembang secara serta-merta dari kandungan masyarakat, menjiwai semua pedoman yang mengatur tingkah-laku warganya. Pengukuhan sistem pranata yang disebut dengan "adat" dan "agama" mencerminkan nilai-nilai praktis, karena hukum adat dan hukum agama itu telah memenuhi fungsi ideologikal dari hukum, yakni "membuat aturan-aturannya dirasakan sebagai aturan yang sesuai (proper) untuk menyalurkan dan mengontrol tingkah-laku anggota masyarakatnya". Dari cara pandang filosofis, rumusan ini merupakan formulasi idiologi dan keyakinan kelompok masyarakat kepada acuan hukum yang mereka pandang paling sesuai dan paling ideal bagi kehidupan sosial mereka. Konsep hukum demikian ini mencerminkan pandangan hidup yang dianutinya, baik berupa nilai asli yang bersumber dari dalam masyarakat itu sendiri, maupun nilai dari hasil serapan, terbentuk melalui proses interaksi berbagai kelompok. Berbagai sistem nilai itu, dalam perjalanannya mengalami "perkembangan" atau "menghilang" kemudian membentuk budaya baru lagi secara kontinum. Konsepsi hukum dimaksud tidak muncul karena inisiatif perundangundangan, melainkan dari praktik sehari-hari yang dituntun oleh suatu lintas hubungan yang adil (reasonable) dalam rangka kerja-sama sosial. Di sini sekaligus bermakna pembedaan pada proses pembentukan hukum dalam "masyarakat negara yang menganut sistem Eropah Kontinental, dimana pembentukan hukum dilakukan oleh badan legislatif. "Sementara pada masyarakat negara yang menganut sistem Common Law, pembentukan hukum lebih dipusatkan pada kewenangan atau fungsi hakim, dimana hukum dipandang sebagai putusan-putusan hakim terhadap suatu kasus, sehingga tradisi common low ini dikenal juga sebagai tradisi case law. ${ }^{16}$ 1980).

${ }^{16}$ Charles Himawan, "The Foreign Investment: Process In Indonesia", (Singapore: 
Berbagai bentuk hukum lokal yang digunakan untuk penyelesaian sengketa-sengketa bisnis itu, tidak hanya mencerminkan kepentingankepentingan mereka yang bersengketa, namun untuk kepentingan "kelangsungan sistem budaya masyarakat keseluruhan". Secara analitik, mencerminkan sistem nilai budaya yang berlangsung, dan secara realistik mampu dilaksanakan atau dipenuhi oleh mereka yang bersengketa dan atau oleh keluarganya. Dalam rangkaian temuan ini, walaupun tidak semua warga masyarakat di l.ingkungannya masing-masing, khususnya pihak-pihak besengketa, mengetahui dan memahami bagaimana aspek-aspek pengaturan "hukum adat, kebiasaan-kebiasaan, tradisi-tradisi, ataupun "hukum agama" atau "norma-norma agama" yang berlaku di lingkungannya, namun mereka meyakini bahwa terdapat "norma-norma ajek yang mengitari kehidupan sosialnya", atau dalam cara pandang Sally Moore bahwa "dalam bidangbidang sosial masyarakat terdapat atiuran-aturan internalnya sendiri-sendiri yang bersifat semi-otonom" Aturan-aturan internal ini, secara literer dikenal sebagai "aturan-aturan yang menguasai kehidupan itu sendiri (living law). Dengan cara pandang demikian ini, norma-norma hukum atau ketentuanketentuan internal yang bersifat semi-otonom digunakan sebagai kerangka acuan penyelesaian sengketa pada ketiga komunitas, dan untuk seberapa boleh penulis artikan sebagai "nilai-nilai budaya yang berlangsung". Nilainilai budaya ini, secara konseptual berlangsung dalam proses interaksi masing-masing individu atai kelompok, bernegosiasi, kemudian melahirkan baik berupa "hukum-hukumnya sendiri" (self regulation) ataupun berupa "hukum rakyat" (endegineus law) berada di luar kontrol hukum negara (state law), kemudian dijadikan kerangka acuan untuk menyelesaikan sengketasengketa hukum di lingkungannya masing-masing.

Secara analitik, fenomena budaya suku Sasak di atas, mendeskripsikan suatu pengakuan, bahwa berbagai pranata hukum lokal eksis pada arena sosialnya masing-masing, dan memiliki keabsahan berlaku bebas di luar ketentuan hukum negara (state law). Jika konsep ini hendak dipahami dari perspektif UU No. 22 Tahun 1999, kemudian diganti dan diubah dengan UU No. 32 Tahun 2004 tentang "Pemerintah Daerah", maka disinilah letak pentingnya untuk memahami bagaimana pranata-pranata hukum lokal, berupa kebiasaan-kebiasaan, tradisi-tradisi (dan oleh UUD '45 Pasal $18 \mathrm{~b}$ yang diamandemen telah diakui keberadaannya) bekerja secara faktual pada arena komunitas, sekurang-kurangnya pada arena komunitas sasaran penelitian, baik untuk keteraturan interaksi antar sesama warga, maupun terutama, untuk memahami perilaku aktual pihak bersengketa dalam proses penelesaian sengketa-sengketa bisnisnya. 


\section{Penutup}

\section{Kesimpulan}

Berdasarkan kegiatan penelitian yang dilakukan selama kurang lebih 6 (enam) bulan pada suku Sasak di pulau Lombok, menghasilkan kesimpulan-kesimpulan sebagai berikut:

1) Dalam konteks budaya suku bangsa Sasak di pulau Lombok, terdapat aturan-aturan lokal (adat atau hukum adat, kebiasaan-kebiasaan, tradisi-tradisi, norma-norma agama) yang digunakan untuk penyelesaian sengketa-sengketa bisnis yang digerakkan oleh orang-orang atau sekelompok orang yang memiliki pengaruh secara sosial selaku pimpinan informal. Fakta ini menunjukkan bahwa pada suku bangsa bersangkutan hidup dan berkemebang aturanaturan lokal dan pimpinan-pimpinan informal sebagai suatu bentuk sistem pengendalian sosial dalam rangka memelihara keteraturan kehidupan komunitas. Kenyataan ini berarti, bahwa hukum perundang-undangan (state law) yang diberlakukan secara meluas oleh negara, "bukan satu-satunya hukum untuk menyelesaikan sengketa-sengketa masyarakat".

2) Penerapan pranata-pranata atau aturan-aturan lokal, menunjukkan bahwa dalam dimensi pluraslisme hukum (legal pluralism), pihak-pihak bersengketa memiliki kebebasan untuk memilih aturan-aturan hukum (choice of law) yang berlaku di lingkungannya, sebagai kerangka acuan penyelesaian sengketa-sengketa bisnis. Kesimpulan ini jugs bermakna, bahwa penyelesaian sengketa di luar pengadilan semakin dirasakan penting artinya untuk memenuhi kebutuhan hukum masyarakat, termasuk dalam pengertian untuk membantu meringankan beban-badan peradilan dalam menyelesaikan sengketa-sengketa hukum yang diperkirakan cendrung semakin meningkat.

3) Prosedur atau mekanisme dan ketentuan-ketentuan hukum yang digunakan untuk penyelessian sengketa diluar pengadilan, tidak sama dengan prosedur dan hukum yang berlaku di pengadilan formal, dan karenanya terdapat kecendrungan masyarakat untuk menghindari pengadilan. Kenyataan ini, di samping karena memang bersengketa di pengadilan bukan kebiasaan masyarakat, dan juga adanya presepsi-presepsi atau cara pandang masyarakat atas hukum (peraturan perundangundangan), sehingga menyebabkan mereka tidak tedalu "akrab" dengan lembaga penyelesaian sengketa di pengadilan formal. 
4) Prinsip-prinsip yang dikandungi oleh nilai-nilai lokal seperti musyawarah (prinsip keadilan), atau prinsip kebersamaan (harmoni), dan prinsip memelihara keteraturan hubungan sosial (kemanfaatan), secara konseptual merupakan wujud nyata dari prinsip-prinsip keadilan dan kemanafaatan yang dikandungi oleh sistem hukum negara. Konklusi ini, memberikan koreksi bahwa nilai-nilai keadilan, ketertiban, kemanfaatan hukum yang dikandungi oleh sistem hukum, tidak semata-mata merupakan dalil-dalil hukum tertulis (state law) yang lebih bersifat normatif, bukan empirik.

\section{Saran}

1) Para hakim pada berbagai tingkat badan peradilan (termasuk lembaga-lembaga penegak hukum lainnya), hendaknya mempelajari dan memahami cara-cara penyelesaian sengketa yang ditumbuhkan sendiri oleh masyarakat. Para penegak hukum perlu memiliki pengetahuan tentang seting sosial-budaya masyarakat dimana mereka bertugas, sehingga dapat mengetahui apakah tindakan dan putusan-putusan yang diambil betentangan dengan nilai-nilai yang hidup ataukah sebaliknya. Saran ini cukup beralasan, mengingat para hakim, polisi, dan jaksa, dalam menjalankan tugas selalu terfokus kepada hukum sentralsitik tanpa mengindahkan "hukum yang hidup" yang harus dilihat sebagai bagian integral dari sistem hukum nasional.

2) Untuk penegakan supremasi hukum, hendaknya antara "hukum perundang-undangan" (state law) dan "hukum tidak tertulis" (non-state law) diletakkan sama pentingnya dalam kebijakan hukum nasional, khususnya dalam rangka realisisasi efektifitas "Otonomi Daerah" di bidang hukum yang mengisyaratkan perlunya pemerintah memperhatikan nilai-nilai sosial budaya masyarakat dalam setiap kebijakan yang akan diambil

3) Perlu dibentuk lembaga-lembaga penyelesaian sengketa di luar pengadilan (desentralisasi penyelesaian sengketa bisnis), baik di tingkat pusat, maupun tingkat daerah, bahkan di lingkunganlingkungan terdekat dengan pemukiman penduduk. Saran ini semakin menjadi relevan, karena berkaitan dengan usaha-usaha ke arah terciptanya mekanisme penyelesaian sengketa secara cepat, prosedur mudah dan murah, tanpa harus mengorbankan masyarakat dengan prosedur-prosedur formal dan biaya-biaya 
yang tidak perlu, sebagaimana sering terjadi pada penyelesaian sengketa hukum sentralsitik.

4) Disarankan untuk dibentuk "hukum acara penyelesaian sengketa di luar pengadilan" yang mudah dipahami, tidak birokratif, dan mencerminkan riasa keadilan, sehingga dapat bermanfaat dalam pemenuhan kebutuhan hukum masyarakat secara keseluruhan. 


\section{Daftar Kepustakaan}

AAG. Peters \& Siswosoebroto. Hukum dan Pembangunan Sosial, Buku Teks Sosiologi Hukum - Buku 1. Jakarta: Pustaka Sinar Harapan, 1988.

Abdullah, Idrus. "Penyelesaian Sengketa Melalui Mekanisme Pranata Lokal: Studi Kasus Dalam Dimensi Pluralisme Hukum Di Lombok Barat", Disertasi, Jakarta: Fakultas Hukum Universitas Indonesia, 2002.

- Penyelesaian Sengketa Bisnis Di Luar Pengadilan Antar Warga Ssama Etnis di Pulau Sumbawa, 2004.

Auerbach, Jerold. Justice Without Law: Law and Acculturation Immigrant Experience, New York: Oxford University Press, 1971.

Crabtree, Benyamin F., \& William L. Muller. "Doing Qualitative Research: Research Method for Primary Care", Vol. 3. Newbury Park London: Sage Publication, 1992.

Yoddumnem-Attig, Beneha, et.al. (ed). Field Manual on Selected Qualitative Research Methods. Thailand Institiute for Population and Social Research, Mehido University, 1993.

Himawan, Charles. The Foreign Investment: Process In Indonesia, Singapore: 1980.

Lev, Daniel. Hukum dan Politik di Indonesia, Jakarta: LP3ES, 1990.

Departemen Pendidikan dan Kebudayaan, Kamus Besar bahasa Indonesia. Jakarta:Balai Pustaka.

. Proyek Penelitian dan Pencatatan Kebudayaan, AdatIstiadat Daerah Nusa Tenggara Beret, 1977-1978 . Sejarah Daerah Nusa Tenggara Barat, 1977-1978.

Galanter. "Justice in Many Rooms: Curt, Private Ordering, and Indigenous Law", dalam Journal of Legal Pluralism, No. 19, tahun 1981: 1-83.

Griffiths, "What is Legal Pluralism?", Journal of Legal Pluralism, 24, London: Miller \& Tunner Ltd., 1986: 1-50.

Meleong, Lexi J. Metodologi Penelitian Kualitatif, Bandung: PT. Remaja Rosdakaria, 1999. 
Harahap, M. Yahya. Penyelesaian Sengketa Di Luar Pengadilan (Alternative Dispute Resolution - ADR), Jakarta: Departemen Kehakiman, 1996.

ÍNader L. dan HF. Todd.(ed.), The Disputing Process - Law in Ten Societes, New York: Columbia University Press, 1978.

Moore, Sally Falk. Law and Social Change: The Semi-Autonomous Social Field an as Appropriate Subjeck of Study, Law as Process- an Anthropological Approach, London. Boston: Routledge Kegan Paul, 1983.

Ihromi, T. O. Bianglala Hukum. Bandung: Tarsito,1986. 